\title{
Macrobiotus polypiformis sp. nov., a new tardigrade (Macrobiotidae; hufelandi group) from the Ecuadorian Pacific coast, with remarks on the claw abnormalities in eutardigrades
}

\author{
Milena ROSZKOWSKA ${ }^{1,{ }^{*},}$, Marta OSTROWSKA ${ }^{2}$, Daniel STEC ${ }^{3}$, \\ Karel JANKO ${ }^{4}$ \& Łukasz KACZMAREK ${ }^{5}$
}

${ }^{1,5}$ Department of Animal Taxonomy and Ecology, Faculty of Biology, Adam Mickiewicz University in Poznań, Umultowska 89, 61-614 Poznań, Poland.

${ }^{2}$ Department of Avian Biology and Ecology, Faculty of Biology,

Adam Mickiewicz University in Poznań, Umultowska 89, 61-614 Poznań, Poland.

${ }^{3}$ Department of Entomology, Institute of Zoology and Biomedical Research

Jagiellonian University, Gronostajowa 9, 30-387 Kraków, Poland.

${ }^{4}$ Laboratory of Fish Genetics, Institute of Animal Physiology and Genetics,

Academy of Sciences of the Czech Republic, Rumburská 89, 277 21, Liběchov, Centre for Polar Ecology, Faculty of Science, University of South Bohemia in České Budějovice, Czech Republic.

${ }^{*}$ Corresponding author: mil.roszkowska@gmail.com

${ }^{2}$ Email: marta.ostrowska@amu.edu.pl

${ }^{3}$ Email: daniel_stec@interia.eu

${ }^{4}$ Email: janko@iapg.cas.cz

${ }^{5}$ Email: kaczmar@amu.edu.pl

${ }^{1}$ urn:Isid:zoobank.org:author:3C2055BD-866C-4B74-8669-A0749C6C9D7D
${ }^{2} \underline{\text { urn:1sid:zoobank.org:author:727B2A95-C68B-4B5F-B732-8429A686AA47 }}$
${ }^{3}$ urn:1sid:zoobank.org:author:C148C15D-9F12-4312-9702-B1E1513C63CC
${ }^{4} \underline{\text { urn:1sid:zoobank.org:author:DA3713CE-1E79-4DC4-9BBE-19CF7A0443E3 }}$
${ }^{5} \underline{\text { urn:Isid:zoobank.org:author:7C4605F4-97C2-4EB8-93A2-C20598AFB63D }}$

\begin{abstract}
From a moss sample collected in the Manabí Province in Ecuador, we extracted 96 specimens of a new species of eutardigrade. No eggs were found. In order to obtain eggs, an in vitro culture was prepared. In total, 136 specimens (including ten simplex), one exuvia and 44 eggs (including two with embryos) of the new species were obtained. In addition to the traditional taxonomic description with morphometrics, light and scanning microscopy imaging, we also provide nucleotide sequences of three nuclear (18S rRNA, 28S rRNA, ITS-2) and one mitochondrial (COI) DNA fragments of the new species. Macrobiotus polypiformis sp. nov. belongs to the hufelandi group and is most similar to Ma. paulinae Stec, Smolak, Kaczmarek \& Michalczyk, 2015, but differs from it mainly by the lack of dorso-lateral patches of granulation on the cuticle, egg processes with longer and more numerous filaments and in some morphometric characters of both eggs and adults. Moreover, we provide a short discussion on the modifications/abnormalities of the claws in eutardigrades and the possible consequences on the taxonomic status of Mesobiotus armatus (Pilato \& Binda, 1996), suggesting its consideration as species inquirenda (with uncertain taxonomic status).
\end{abstract}


Keywords. DNA barcoding, Eutardigrada, new species, Neotropic, water bears.

Roszkowska M., Ostrowska M., Stec D., Janko K. \& Kaczmarek Ł. 2017. Macrobiotus polypiformis sp. nov., a new tardigrade (Macrobiotidae; hufelandi group) from the Ecuadorian Pacific coast, with remarks on the claw abnormalities in eutardigrades. European Journal of Taxonomy 327: 1-19. https://doi.org/10.5852/ejt.2017.327

\section{Introduction}

Ecuador, located in the north-western part of South America, is divided into three main regions: the western coastal lowlands, the Andean mountain range and the eastern Amazon Basin (the Oriente) (St Louis et al. 2009). Ecuador also owns the Galápagos Islands, situated about 1,000 km west of the mainland.

Manabí is one of the Ecuadorian provinces located in the coastal region. In terms of area, it is the largest province on the coast and the fifth in the country. The climate there is determined by the Humboldt Current and the weather phenomenon El Niño, and oscillates from subtropical and dry on the coast to wet and extremely humid further inland.

The Phylum Tardigrada consists of over 1,200 species (Guidetti \& Bertolani 2005; Degma \& Guidetti 2007; Degma et al. 2009-2016; Vicente \& Bertolani 2013), inhabiting terrestrial, freshwater and marine environments throughout the world (Ramazzotti \& Maucci 1983; McInnes 1994; Nelson et al. 2015).

Tardigrades of South America are very poorly known and, until now, only 227 taxa have been reported from this region (ca 18\% of all known species) (Kaczmarek et al. 2015 and literature cited therein; Londoño et al. 2015; Roszkowska et al. 2015, 2016). Water bears are known best from Argentina, Chile and Brazil with 119, 63 and 61 taxa, respectively. In comparison, the Ecuadorian tardigrade fauna is almost unknown, with only 21 species reported from this region to date (Kaczmarek et al. 2015 and literature cited therein). Among them, only one species of the Macrobiotus hufelandi group was recorded: Ma. hibiscus de Barros, 1942. However, this species has an uncertain taxonomic position and geographic distribution, and needs redescription (Kaczmarek et al. 2015).

The Macrobiotus hufelandi group is a cosmopolitan complex with 42 known species (Stec et al. 2015; Bąkowski et al. 2016). They are characterized by the presence of an oral cavity armature composed of three rows of teeth (sometimes visible only in SEM), two macroplacoids and a microplacoid in the pharynx, and eggs with processes in the shape of inverted goblets. The great majority of the hufelandi group species exhibit a restricted distribution (e.g., Ma. iharosi Pilato, Binda \& Catanzaro, 1991, known from Democratic Republic of Congo, the Republic of South Africa and Tanzania; Ma. madegassus Maucci, 1993, known only from Madagascar; Ma. patagonicus Maucci, 1988 known only from Argentina and Chile) or are known only from their type localities (e.g., Ma. anemone Meyer, Domingue \& Hilton, 2014, known only from Louisiana (USA); Ma. kristenseni Guidetti, Peluffo, Rocha, Cesari \& Moly de Peluffo, 2013 or Ma. kazmierskii Kaczmarek \& Michalczyk, 2009, known only from southern Argentina) (Kaczmarek et al. 2015, 2016).

In this paper we describe a new species of the hufelandi group, Macrobiotus polypiformis sp. nov., collected from the Ecuadorian Pacific coast, in Manabí Province. We have used an integrative approach (SEM observation and DNA sequencing, together with in vitro culturing) and as a result we were able to observe and describe details of egg morphology that would probably have been overlooked using solely traditional taxonomic tools. We also discuss the presence of modifications/abnormalities in tardigrade claws and their consequences for the taxonomic status of Mesobiotus armatus (Pilato \& Binda, 1996). 


\section{Material and methods}

\section{Sample processing and culturing of specimens}

The moss sample from a concrete wall was collected by Milena Roszkowska and Łukasz Kaczmarek on the $3^{\text {rd }}$ of January 2015 in the Manabí Province, Ecuador. The sample was collected and examined for terrestrial tardigrades using standard methods (Dastych 1980), with modifications described in Stec et al. (2015). After extraction, a total of 96 tardigrades and no eggs of the new species were obtained. Of these, 84 specimens were mounted on microscope slides in Hoyer's medium and the remaining 12, in order to obtain eggs, were placed in a plastic Petri dish containing "Żywiec Zdrój” spring water and unicellular freshwater algae (Chlorococcum sp. and Chlorella sp.). To aid tardigrade locomotion, the Petri dish bottom was scratched with fine sandpaper. The culture was maintained at room temperature $\left(\mathrm{ca} 22^{\circ} \mathrm{C}\right.$ ) and out of direct sunlight. After a few weeks of culturing, 7 adults and 29 eggs were obtained. All were mounted on microscope slides in Hoyer's medium.

To enable Scanning Electron Microscope (SEM) observation and DNA sequencing, another sample extraction and culture was undertaken. From this second laboratory culture, 25 adults and 15 eggs were prepared for SEM analysis and eight individuals were used for DNA extraction and sequencing.

All measurements and photomicrographs were taken using an Olympus BX41 phase contrast microscope (PCM) associated with an ARTCAM-300Mi digital camera (Olympus Corporation, Shinjuku-ku, Japan) and Olympus BX63 differential interference contrast (DIC) associated with an Olympus XC10 camera (Olympus Corporation, Shinjuku-ku, Japan). In order to obtain clean and fully extended specimens for SEM, tardigrades and their eggs were prepared using methods described in Stec et al. (2015). Animals and eggs were examined under high vacuum in a Versa 3D DualBeam Scanning Electron Microscope at the ATOMIN facility of the Jagiellonian University, Kraków, Poland.

Sample size for morphometry was chosen following recommendations by Stec et al. (2016a). All measurements, made with the QuickPhoto Camera 2.3 software, are given in micrometres $(\mu \mathrm{m})$. Structures were measured only if their orientation was suitable. Body length was measured from the anterior extremity to the end of the body, excluding the hind legs. The terminology used to describe buccal apparatus and more specifically the oral cavity armature, and used in differential diagnoses, follows Michalczyk \& Kaczmarek (2003) and Guidetti et al. (2012). Buccal tube length and the level of the stylet support insertion point were measured according to Pilato (1981). The buccal tube width was measured as the external and internal diameter at the level of the stylet support insertion point. The macroplacoid length sequence is given according to Kaczmarek et al. (2014). Lengths of the claw branches were measured from the base of the claw to the top of the branch, excluding lunules, but including accessory points. The $p t$ ratio is the ratio of the length of a given structure to the length of the buccal tube expressed as a percentage (Pilato 1981). The distance between egg processes was measured as the shortest line connecting the base edges of the two closest processes. Morphometric data were handled using the "Macrobiotidae" ver. 1.2 template available from the Tardigrada Register (Michalczyk \& Kaczmarek 2013). Tardigrade taxonomy follows Bertolani et al. (2014).

\section{Genotyping}

Eight individuals were used for DNA isolation and sequencing. Each specimen was identified under LM before DNA extraction. The goal was to amplify four commonly used molecular markers: $18 \mathrm{~S}$ rRNA, 28S rRNA, ITS-2, COI. The first three of these are nuclear whereas COI is a mitochondrial marker. These markers differ in mutation rate. The first two are conservative, while the last two are characterised by a relatively high mutation rate, making them suitable for different purposes. The $18 \mathrm{~S}$ rRNA together with 28S rRNA are used for resolving relationships at higher taxonomic levels such as families and genera (e.g., Bertolani et al. 2014) whereas COI and ITS-2 are appropriate for examining intra and inter- 
Table 1. Primers used for sequencing of four DNA fragments (one mitochondrial and three nuclear) of Macrobiotus polypiformis sp. nov.

\begin{tabular}{lllll}
\hline DNA fragment & $\begin{array}{l}\text { Primer } \\
\text { name }\end{array}$ & $\begin{array}{l}\text { Primer } \\
\text { direction }\end{array}$ & Primer sequence (5'-3') & Source \\
\hline 18S rRNA & SSU01_F & forward & AACCTGGTTGATCCTGCCAGT & Sands et al. (2008) \\
& SSU82_R & reverse & TGATCCTTCTGCAGGTTCACCTAC & Sands et al. (2008) \\
28S rRNA & 28SF0001 & forward & ACCCVCYNAATTTAAGCATAT & Mironov et al. (2012) \\
& 28 SR0990 & reverse & CCTTGGTCCGTGTTTCAAGAC & Mironov et al. (2012) \\
COI & LCO1490 & forward & GGTCAACAAATCATAAAGATATTGG & Folmer et al. (1994) \\
& HCO2198 & reverse & TAAACTTCAGGGTGACCAAAAAATCA & Folmer et al. (1994) \\
ITS-2 & ITS3 & forward & GCATCGATGAAGAACGCAGC & White et al. (1990) \\
& ITS4 & reverse & TCCTCCGCTTATTGATATGC & White et al. (1990) \\
\hline
\end{tabular}

specific genetic variation (e.g., Hebert et al. 2003; Cesari et al. 2009; Bertolani et al. 2011; Wełnicz et al. 2011; Vicente \& Bertolani 2013; Morek et al. 2016).

DNA extraction from single individuals was carried out according to the protocol by Casquet et al. (2012) with modification described in detail in Stec et al. (2015). The method comprises two major reagents; 75-150 $\mu \mathrm{m}$ wet bead Chelex ${ }^{\circledR} 100$ resin (Bio-Rad) material chelating $\mathrm{Mg}^{2+}$ ions which are cofactors of DNAses (DNA protection from degradation) and Proteinase K (Qiagen ${ }^{\circledR}$ ) which digests proteins in cell membranes.

Amplification of each DNA fragment (PCR) was conducted in a total volume of $20.0 \mu \mathrm{l}$ (see Table 1 for primers; for PCR cocktails and programs see Stec et al. 2015). Separation of PCR products were carried out by $1 \%$ agarose gel electrophoresis stained with Midori Green (Nippon Genetics) and purified with the NucleoSpin ${ }^{\circledR}$ Gel and PCR Clean-up kit and suspended in $20.0 \mu \mathrm{l}$ of Tris/HCl $(5 \mathrm{mM})$. Sequencing reactions were done in a total volume of $10.0 \mu \mathrm{l}$ containing: $1.0 \mu \mathrm{l} 5 \times$ buffer, $1.0 \mu \mathrm{l}$ BrightDye ${ }^{\circledR}$ Terminator Cycle Sequencing Kit v3.1 (Nimagen), $0.15 \mu \mathrm{l}$ of a primer $\left(10 \mathrm{pmol} \mu \mathrm{l}^{-1}\right), 2.0 \mu \mathrm{l}$ of the purified PCR product, and $5.85 \mu \mathrm{l}$ of ddH2O. Sequencing settings were: an initial denaturation at $96^{\circ} \mathrm{C}$ for $1 \mathrm{~min}$, followed by 25 cycles of denaturation at $96^{\circ} \mathrm{C}$ for $10 \mathrm{sec}$, annealing at $55^{\circ} \mathrm{C}$ for $5 \mathrm{sec}$, and elongation at $60^{\circ} \mathrm{C}$ for $4 \mathrm{~min}$ (28S rRNA, COI and ITS-2) or $8 \mathrm{~min}$ (18S rRNA). In order to obtain good reads and avoid reading errors, sequencing reactions were carried out in both directions. Sequencing products were then purified with the ExTerminator kit (A\&A Biotechnology) and suspended in $25 \mu \mathrm{l}$ of formamide. Sequencing products were read with the ABI 3130xl sequencer at the Molecular Ecology Lab, Institute of Environmental Sciences of the Jagiellonian University, Kraków, Poland. Sequences were processed in BioEdit ver. 7.2.5 (Hall 1999).

Obtained sequences for the four DNA fragments were checked using Basic Local Alignment Search Tool (BLAST; Altschul et al. 1990) to verify eventual identity with sequences deposited in GenBank. In order to compare molecular similarity of the new species with other taxa, sequences from several other species belonging to the Macrobiotus hufelandi group were used (Table 2).

All sequences were aligned with the ClustalW Multiple Alignment tool (Thompson et al. 1994) implemented in BioEdit. Then, the aligned sequences were trimmed to: 328 (ITS-2), 621 (COI), 710 (28S rRNA), 808 (18S rRNA) bp. Uncorrected pairwise genetic distances were calculated using MEGA version 4 (Tamura et al. 2007).

Raw data underlying the description of Macrobiotus polypiformis sp. nov. are deposited in the Tardigrada Register (Michalczyk \& Kaczmarek 2013) under www.tardigrada.net/register/0038.htm (and in the Supplementary Data). DNA sequences were deposited in GenBank (www.ncbi.nlm.nih.gov/genbank). 
Table 2. Sequences used for molecular comparison of Macrobiotus polypiformis sp. nov. with several other species from the Macrobiotus hufelandi group.

\begin{tabular}{|c|c|c|c|}
\hline $\begin{array}{l}\text { DNA } \\
\text { marker }\end{array}$ & Species & Accession number & Source \\
\hline \multirow{3}{*}{ ITS-2 } & Ma. polonicus Pilato et al, 2003 & HM150647 & Wełnicz et al. 2011 \\
\hline & Ma. sapiens Binda \& Pilato, 1984 & GQ403680 & Schill et al. 2010 \\
\hline & Ma. paulinae Stec et al., 2015 & KT935500 & Stec et al. 2015 \\
\hline \multirow{8}{*}{$\mathrm{COI}$} & Ma.cf. hufelandi & HQ876589-94, HQ876596 & Guidetti et al. 2013 \\
\hline & Ma. h. hufelandi C.A.S. Schultze, 1834 & HQ876584, HQ876586-8 & Guidetti et al. 2013 \\
\hline & Ma. macrocalix Bertolani \& Rebecchi, 1993 & FJ176203-17, HQ876571 & Guidetti et al. 2013 \\
\hline & Ma. kristenseni Guidetti et al., 2013 & KC193575-6 & Guidetti et al. 2013 \\
\hline & Ma. vladimiri Bertolani et al., 2011 & HM136931-4, HQ876568 & Guidetti et al. 2013 \\
\hline & Ma. terminalis Bertolani \& Rebecchi, 1993 & JN673960, AY598775 & Guidetti et al. 2013 \\
\hline & Ma. sandrae Bertolani \& Rebecchi, 1993 & HQ876566-70, HQ876572-83 & Guidetti et al. 2013 \\
\hline & Ma. paulinae Stec et al., 2015 & KT951668 & Stec et al. 2015 \\
\hline \multirow{2}{*}{$28 \mathrm{~S}$} & Ma. hufelandi gr. & FJ435751, FJ435754-5 & Guil \& Giribet 2012 \\
\hline & Ma. paulinae Stec et al., 2015 & KT935501 & Stec et al. 2015 \\
\hline \multirow{8}{*}{$18 \mathrm{~S}$} & Ma. h. hufelandi C.A.S. Schultze, 1834 & GQ849024, X81442 & Bertolani et al. 2014 \\
\hline & Ma. hufelandi gr. & HQ604971, FJ435738-40 & Bertolani et al. 2014 \\
\hline & Ma. kristenseni Guidetti et al., 2013 & KC193577 & Bertolani et al. 2014 \\
\hline & Ma. macrocalix Bertolani \& Rebecchi, 1993 & HQ604976 & Bertolani et al. 2014 \\
\hline & Ma. polonicus Pilato et al., 2003 & HM187580 & Bertolani et al. 2014 \\
\hline & Ma. sapiens Binda \& Pilato, 1984 & DQ839601 & Bertolani et al. 2014 \\
\hline & Ma. joannae Pilato \& Binda, 1983 & HQ604974-5 & Bertolani et al. 2014 \\
\hline & Ma. paulinae Stec et al., 2015 & KT935502 & Stec et al. 2015 \\
\hline
\end{tabular}

\section{Abbreviations}

$\mathrm{LM} \quad=$ light microscopy

MECN = Museo Ecuatoriano de Ciencias Naturales, Sección de Entomología, Rumipamba 341 y Av. de los Shyris, Quito, Ecuador

DATE = Department of Animal Taxonomy and Ecology, Institute of Environmental Biology, Adam Mickiewicz University in Poznań, Umultowska 89, 61-614 Poznań, Poland

ZMUC = Zoological Museum, Natural History Museum of Denmark, University of Copenhagen, Universitetsparken 15, DK-2100 Copenhagen Ø, Denmark 


\section{Results}

Phylum Tardigrada Doyère, 1840

Class Eutardigrada Richters, 1926

Order Parachela Schuster, Nelson, Grigarick \& Christenberry, 1980

Superfamily Macrobiotoidea Thulin, 1928 (in Marley et al. 2011)

Family Macrobiotidae Thulin, 1928

Genus Macrobiotus C.A.S. Schultze, 1834

Macrobiotus polypiformis sp. nov.

urn:1sid:zoobank.org:act:3858645A-2909-4DB9-82CD-CF2B4D7051C2

Figs 1-29; Tables 3-4

\section{Etymology}

The specific epithet 'polypiformis' refers to the similarity of the egg processes to the polyp form found in the phylum Cnidaria.

\section{Material examined}

Specimens mounted on microscope slides in Hoyer's medium, fixed on SEM stubs or processed for DNA sequencing.
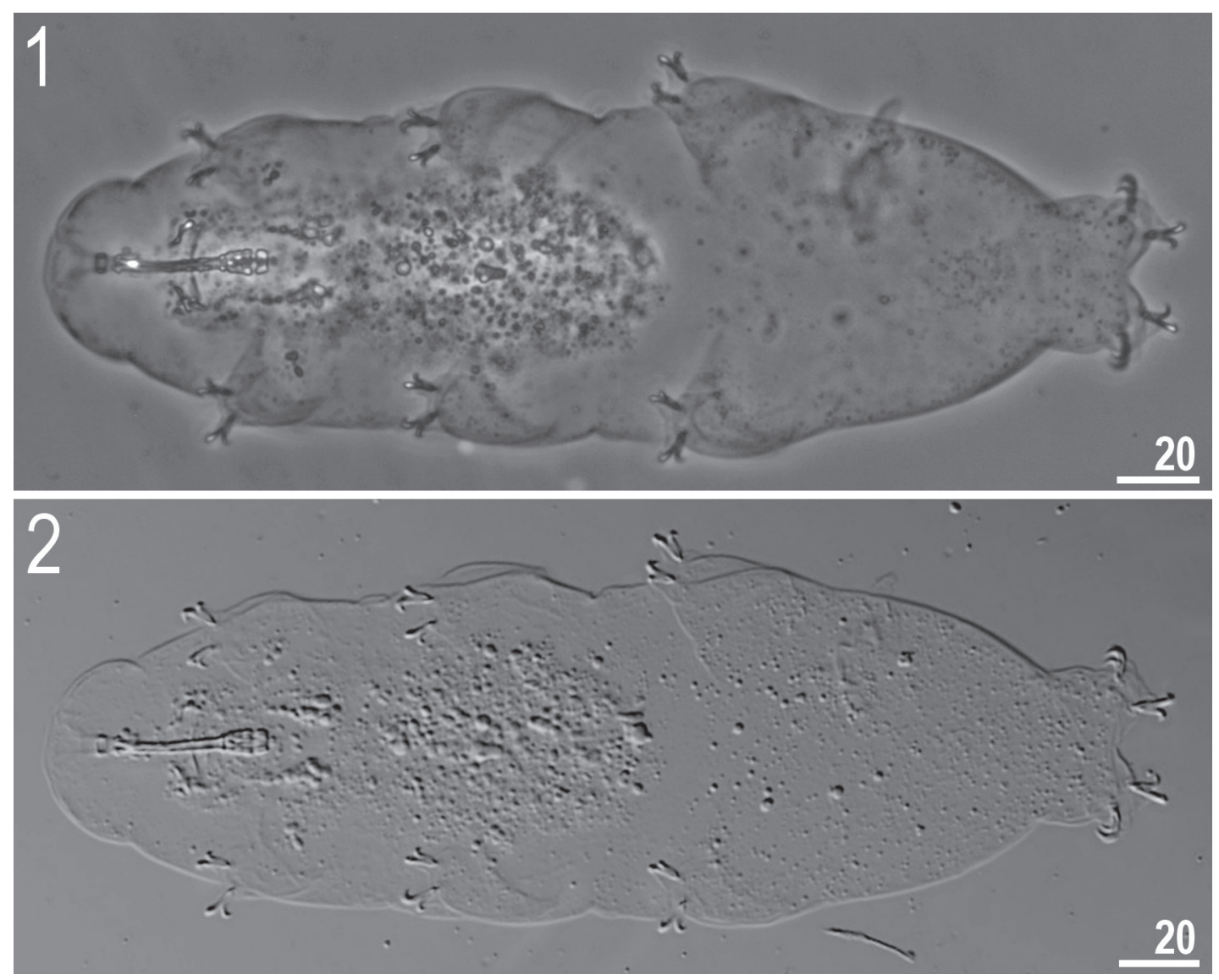

Figs 1-2. Macrobiotus polypiformis sp. nov., holotype, habitus, dorso-ventral projection. 1. Seen in PCM. 2. Seen in DIC. Scale bars in $\mu \mathrm{m}$. 
Table 3. Measurements (in $\mu \mathrm{m}$ ) of selected morphological structures of individuals of Macrobiotus polypiformis sp. nov. mounted in Hoyer's medium $(\mathrm{N}=$ number of specimens/structures measured; Range $=$ the smallest and the largest structure among all measured specimens; $\mathrm{SD}=$ standard deviation).

\begin{tabular}{|c|c|c|c|c|c|c|c|c|c|}
\hline \multirow{2}{*}{ Character } & \multirow{2}{*}{$\mathbf{N}$} & \multicolumn{2}{|c|}{ Range } & \multicolumn{2}{|c|}{ Mean } & \multicolumn{2}{|c|}{ SD } & \multicolumn{2}{|c|}{ Holotype } \\
\hline & & $\mu \mathrm{m}$ & $p t$ & $\mu \mathbf{m}$ & $p t$ & $\mu \mathbf{m}$ & $p t$ & $\mu \mathrm{m}$ & $p t$ \\
\hline Body length & 30 & $237-375$ & - & 327 & & 57 & & 268 & - \\
\hline \multicolumn{10}{|l|}{ Buccopharyngeal tube } \\
\hline Buccal tube length & 30 & $24.4-32.5$ & - & 29.2 & - & 2.5 & - & 26.4 & - \\
\hline Stylet support insertion point & 30 & $17.1-23.5$ & $70.1-72.9$ & 20.9 & 71.6 & 1.9 & 0.9 & 18.9 & 71.6 \\
\hline Buccal tube external width & 29 & $2.8-4.0$ & $11.0-13.0$ & 3.4 & 11.8 & 0.4 & 0.6 & 2.9 & 11.0 \\
\hline Buccal tube internal width & 29 & $1.6-2.4$ & $6.1-8.6$ & 2.0 & 6.9 & 0.3 & 0.6 & 1.6 & 6.1 \\
\hline Ventral lamina length & 26 & $13.5-17.3$ & $52.1-55.1$ & 15.8 & 53.4 & 1.3 & 1.0 & 14.0 & 53.0 \\
\hline \multicolumn{10}{|l|}{ Placoid lengths } \\
\hline Macroplacoid 1 & 30 & $5.2-6.8$ & $19.2-23.5$ & 6.2 & 21.3 & 0.7 & 1.3 & 5.6 & 21.2 \\
\hline Macroplacoid 2 & 30 & $2.8-4.1$ & $11.4-14.5$ & 3.6 & 12.4 & 0.5 & 0.8 & 3.2 & 12.1 \\
\hline Microplacoid & 29 & $1.5-2.3$ & $5.8-7.1$ & 1.8 & 6.3 & 0.2 & 0.4 & 1.6 & 6.1 \\
\hline Macroplacoid row & 30 & $9.0-11.8$ & $34.3-39.9$ & 10.8 & 36.9 & 1.1 & 1.8 & 9.6 & 36.4 \\
\hline Placoid row & 29 & $11.1-14.5$ & $41.4-49.0$ & 13.0 & 44.4 & 1.4 & 2.2 & 11.7 & 44.3 \\
\hline \multicolumn{10}{|l|}{ Claw 1 lengths } \\
\hline External primary branch & 28 & $8.2-11.5$ & $31.4-38.1$ & 10.2 & 34.8 & 1.0 & 1.5 & 9.7 & 36.7 \\
\hline External secondary branch & 27 & $6.6-8.7$ & $25.0-29.8$ & 8.0 & 27.3 & 0.8 & 1.6 & 7.8 & 29.5 \\
\hline Internal primary branch & 28 & $7.7-10.6$ & $30.0-35.4$ & 9.5 & 32.5 & 0.9 & 1.3 & 8.7 & 33.0 \\
\hline Internal secondary branch & 25 & $6.0-8.6$ & $24.3-28.3$ & 7.9 & 26.6 & 0.8 & 1.3 & 6.9 & 26.1 \\
\hline \multicolumn{10}{|l|}{ Claw 2 lengths } \\
\hline External primary branch & 30 & $8.9-12.7$ & $36.0-42.3$ & 11.0 & 37.8 & 1.1 & 1.7 & 9.6 & 36.4 \\
\hline External secondary branch & 30 & $6.8-9.4$ & $27.0-32.6$ & 8.5 & 29.1 & 0.8 & 1.8 & 7.7 & 29.2 \\
\hline Internal primary branch & 30 & $7.8-11.0$ & $30.6-35.1$ & 9.6 & 32.9 & 0.9 & 1.3 & 8.6 & 32.6 \\
\hline Internal secondary branch & 25 & $6.3-8.7$ & $24.1-28.6$ & 7.8 & 26.7 & 0.7 & 1.3 & 7.0 & 26.5 \\
\hline \multicolumn{10}{|l|}{ Claw 3 lengths } \\
\hline External primary branch & 30 & $8.9-12.7$ & $36.1-41.9$ & 11.1 & 38.0 & 1.0 & 1.3 & 9.9 & 37.5 \\
\hline External secondary branch & 28 & $7.0-9.5$ & $27.7-31.9$ & 8.7 & 29.6 & 0.8 & 1.4 & 8.1 & 30.7 \\
\hline Internal primary branch & 28 & $7.9-11.1$ & $31.9-37.1$ & 9.8 & 33.8 & 1.0 & 1.3 & 8.5 & 32.2 \\
\hline Internal secondary branch & 24 & $6.5-9.7$ & $26.2-31.6$ & 8.4 & 28.5 & 0.9 & 1.7 & 7.0 & 26.5 \\
\hline \multicolumn{10}{|l|}{ Claw 4 lengths } \\
\hline Anterior primary branch & 29 & $8.6-12.7$ & $35.2-42.6$ & 11.2 & 38.4 & 1.3 & 2.1 & 10.1 & 38.3 \\
\hline Anterior secondary branch & 26 & $7.1-10.5$ & $27.1-33.4$ & 9.0 & 30.4 & 1.0 & 2.1 & 7.2 & 27.3 \\
\hline Posterior primary branch & 29 & $9.5-14.0$ & $38.3-44.0$ & 12.1 & 41.4 & 1.3 & 1.7 & 10.8 & 40.9 \\
\hline Posterior secondary branch & 29 & $7.1-10.0$ & $26.0-33.8$ & 8.9 & 30.5 & 0.8 & 2.1 & 8.7 & 33.0 \\
\hline
\end{tabular}

\section{Holotype}

ECUADOR: slide 1215/19, 3 Jan. 2015, Milena Roszkowska and Łukasz Kaczmarek leg. (MECN).

\section{Paratypes}

ECUADOR: 135 animals (including 10 simplex), one exuvia and 44 eggs (including two with developed embryos), same data as holotype (MECN, slide 1215/19 (with holotype), 4 paratypes (slides: 1215/*, where the asterisk can be substituted by any of the following numbers: 23, 25) and two eggs (slides: 1215/*: 8, 9); DATE, 92 paratypes (slides: $1215 / *: 1,2,3,10,11,12,13,14,15,16,19,20,22,24$ ) and 24 eggs (slides: 1215/*: 1, 4, 5, 7, 26, 27); ZMUC, 5 paratypes (slides 1215/*: 17, 21) and 3 eggs (slide $1215 / 6))$. 


\section{Type locality}

ECUADOR: Manabí Province, $1^{\circ} 04^{\prime} 06^{\prime \prime} \mathrm{S}, 89^{\circ} 52^{\prime} 18^{\prime \prime} \mathrm{W} ; 370 \mathrm{~m}$ asl, moss sample from a concrete wall, next to E15 road, ca $3.5 \mathrm{~km} \mathrm{~W}$ from San Lorenzo, tropical rainforest.

\section{Description}

Animals (measurements and statistics in Table 3)

Body white in juveniles and adults, transparent after fixation in Hoyer's medium (Figs 1-2). Eyes present (in 93\% of measured specimens). Dorsal and ventral cuticle smooth under LM. Additionally, small oval and round pores (0.9-1.2 $\mu \mathrm{m}$ in diameter), sometimes difficult to observe under LM, are scattered randomly on the entire cuticle (Figs 3-4). A ring of pores, difficult to observe under LM, is present around the mouth opening, below the peribuccal sensory lobes. One patch of fine and dense granulation above claws on legs I-IV present (Figs 16-19).

Mouth antero-ventral. Bucco-pharyngeal apparatus of the Macrobiotus type (Figs 5-6), with the ventral lamina and ten small peribuccal lamellae (Figs 6,9 ) followed by six buccal sensory lobes. Oral cavity armature composed of three bands of teeth, of which only the third band is visible under LM (Fig. 7, empty arrowhead). SEM is required to reveal the first and the second bands of teeth (see Figs 8-9). The first band of teeth comprises extremely small cones arranged in 3-4 rows situated at the anterior portion of the oral cavity, at the base of the peribuccal lamellae (Figs 8-9, filled arrowheads). The second band of teeth is composed of 4-5 rows of small cones (but larger than those on the first band), positioned towards the rear of the oral cavity, between the ring fold and the third band of teeth (Figs 8-9, arrows). The teeth of the third band are positioned at the rear of the oral cavity, between the second band of teeth and the buccal tube opening (Figs 7-9, empty arrowheads).
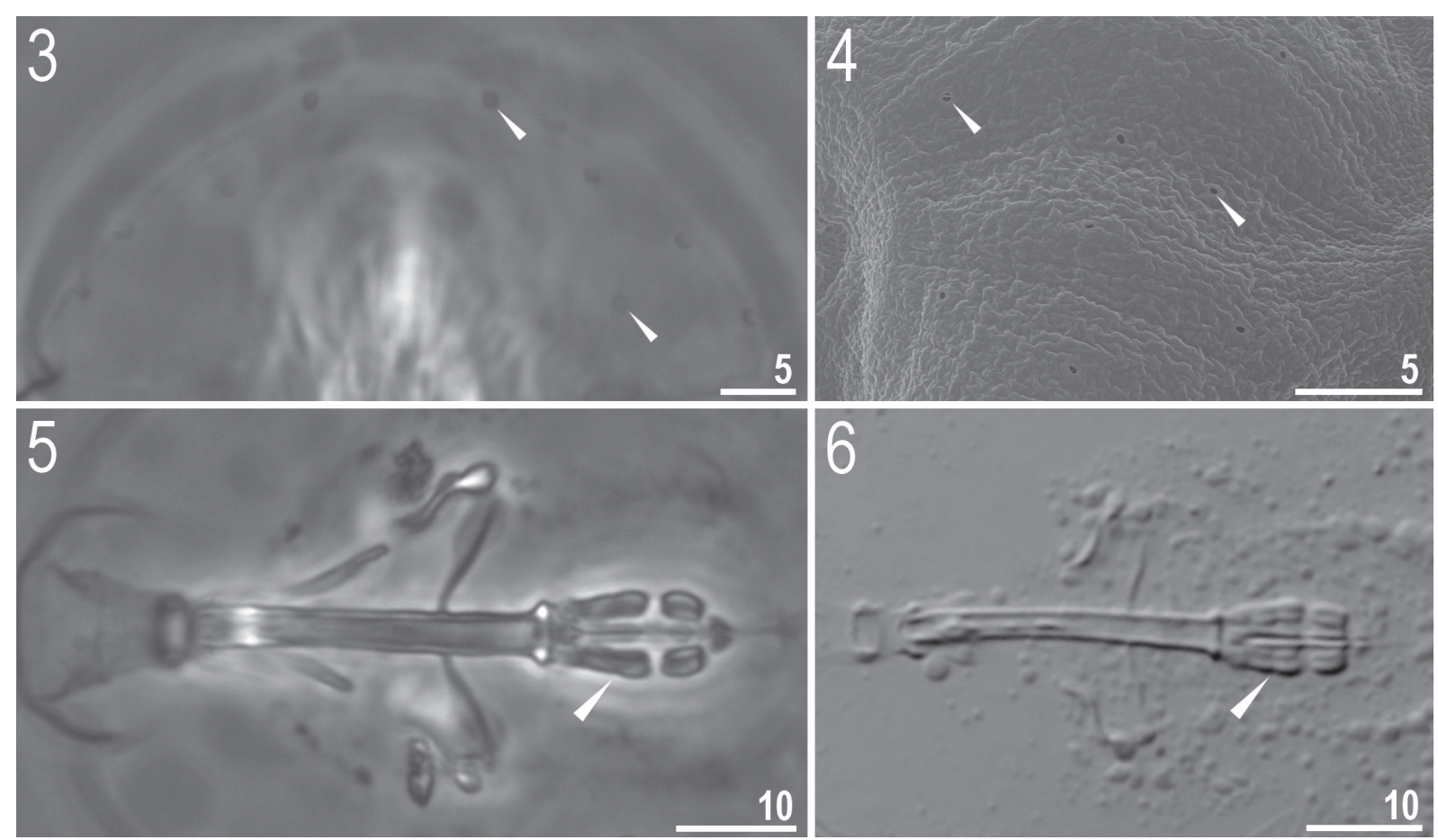

Figs 3-6. Macrobiotus polypiformis sp. nov. 3. Cuticular pores visible in PCM (paratype). 4. Cuticular pores visible in SEM (paratype). 5-6. Bucco-pharyngeal apparatus (dorso-ventral projection), the filled arrowhead indicates the first macroplacoid with central constriction (Fig. 5 = paratype in PCM; Fig. $6=$ holotype in DIC). Scale bars in $\mu \mathrm{m}$. 
Under LM, the teeth of the third band appear as a single, thin, transversal ridge both ventrally and dorsally (Fig. 7, empty arrowhead). Although SEM reveals that both ventral and dorsal teeth do indeed form continuous ridges, there are evident median (M) and lateral (L) peaks corresponding to the median and lateral teeth found in species with better developed oral cavity armatures (Figs 8-9). Median teeth are smaller than the lateral teeth (Fig. 8). In addition, there are a number of smaller accessory teeth (a) placed laterally to the lateral teeth. These accessory teeth are better developed ventrally than dorsally (Fig. 8). Pharyngeal bulb spherical, with triangular apophyses, two rod-shaped macroplacoids and a triangular microplacoid (Figs 5-6). The macroplacoid length sequence $1>2$. The first macroplacoid with a central constriction (Figs 5-6, the filled arrowhead).

Claws small and slender of the hufelandi type (Figs 10-14). Primary branches with distinct accessory points. Lunules on legs I-III smooth (Figs 10, 13), those on legs IV dentate (Figs 12, 14). Bars under claws absent but paired muscle attachments below claws I-III present (hardly visible under LM and only slightly more visible under SEM).

Eggs (measurements and statistics in Table 4)

Laid freely, white to light yellow, spherical and with a hufelandi type chorion ornamentation (Figs 20-28). The surface between processes is covered with a dense regular reticulum (mesh diameter $0.5-$ $0.8 \mu \mathrm{m}$ ) (Figs 22, 25-28). Processes in the shape of inverted goblets with slightly concave, conical, micro-granulated trunks and well-defined terminal discs (Figs 22-23, 25-26, 28). When observed under SEM, some process trunks have 3-5 faint, annular ring undulations (Figs 26, 28), whereas in LM these undulations are not visible. Terminal discs are cog-shaped, with each of the $8-10$ 'cog-teeth' extended to form a long, thin, hair-like and flexible filament that probably serves to enhance the adhesive function of egg processes. Under SEM, small rounded granules or aggregations of granules, $0.06-0.15 \mu \mathrm{m}$ in diameter, are visible on the filaments (Fig. 29). Central area of the terminal disc with sparse, randomly distributed, small granules (Figs 25, 28). Moreover, the area between the granules on the filaments, the surface of the terminal disk and the trunk of the processes appear, under SEM, to be micro-granulated (Figs 28-29).

\section{DNA sequences}

Initially, four molecular markers obtained from four of the eight individuals were sequenced. The sequences from 18S rRNA, 28S rRNA, ITS-2 exhibited a lack of polymorphism, whereas for COI two distinct haplotypes were obtained. Knowing that ITS-2 and COI have relatively high mutation rates,
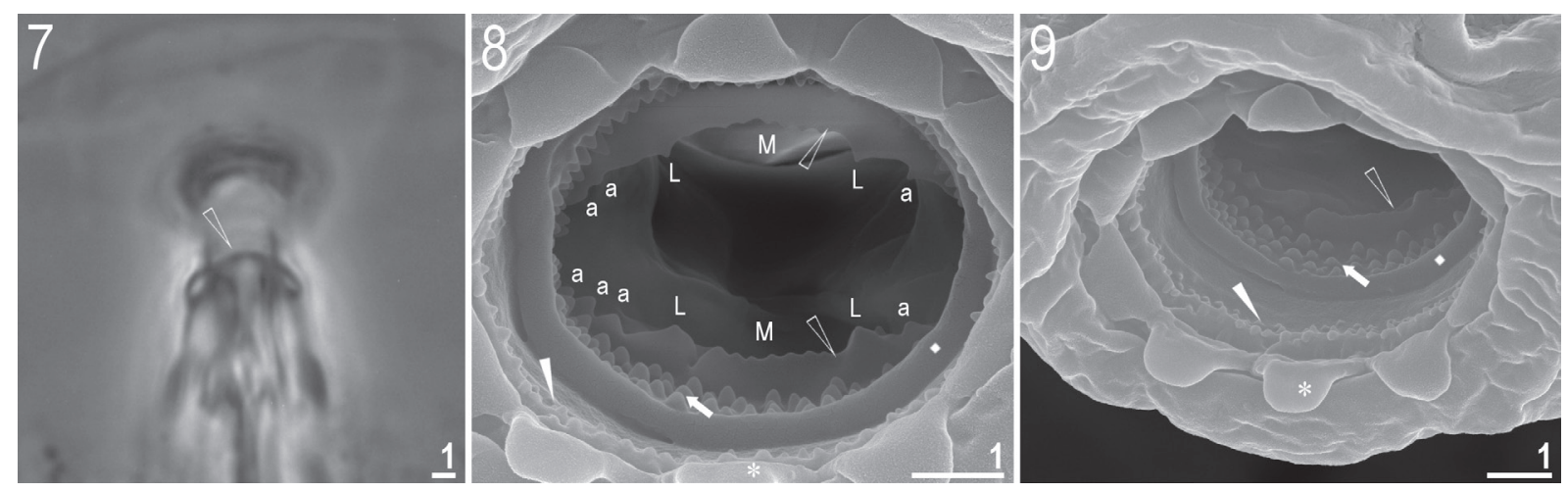

Figs 7-9. Macrobiotus polypiformis sp. nov., paratypes. 7. Third band of teeth visible under PCM (empty arrowhead). 8-9. Oral cavity armature (SEM), the filled arrowheads indicate teeth of the first band, arrows indicate teeth of the second band, the empty arrowheads indicate teeth of the third band, $\mathrm{M}=$ median teeth, $\mathrm{L}=$ lateral teeth, $\mathrm{a}=$ accessory teeth, rhombi $=$ ring folds, asterisks $=$ ventral side. 
Table 4. Measurements (in $\mu \mathrm{m}$ ) of selected morphological structures of eggs of Macrobiotus polypiformis sp. nov. mounted in Hoyer's medium $(\mathrm{N}=$ number of eggs/structures measured; Range $=$ the smallest and the largest structure among all measured specimens; $\mathrm{SD}=$ standard deviation).

\begin{tabular}{lcccc}
\hline Character & N & Range & Mean & SD \\
\hline Diameter of egg without processes & 20 & $61.9-70.5$ & 66.7 & 2.2 \\
Diameter of egg with processes & 16 & $70.4-81.2$ & 76.7 & 2.8 \\
Process height & 60 & $4.3-6.5$ & 5.5 & 0.5 \\
Process base width & 60 & $3.3-5.9$ & 4.5 & 0.5 \\
Process base/height ratio & 42 & $69 \%-91 \%$ & $80 \%$ & $6 \%$ \\
Terminal disc width & 60 & $2.7-5.1$ & 3.9 & 0.5 \\
Distance between processes & 60 & $3.0-7.0$ & 4.8 & 0.9 \\
Number of processes on the egg circumference & 18 & $19-23$ & 21.1 & 1.5 \\
\hline
\end{tabular}

these fragments were sequenced for the remaining four specimens. The eight individuals were found to have identical ITS-2 sequences while COI revealed two haplotypes (frequency 1:1) differing by 20 substitutions. One consensus sequence for each nuclear marker and one consensus sequence for each COI haplotype were deposited in GenBank: 18S rRNA sequence, 1726 bp long (GenBank accession number: KX810008), 28S rRNA sequence, 725 bp long (KX810009), COI sequence for haplotype 1, 658 bp long (KX810011), COI haplotype 2, 658 bp long (KX810012), and ITS-2 sequence, 425 bp long (KX810010).

\section{Remark}

Among the 136 individuals of the new species, one specimen had abnormal claws, i.e., internal and external claw II and III on one leg had additional secondary branches (Figs 15, 19). Additionally, on the
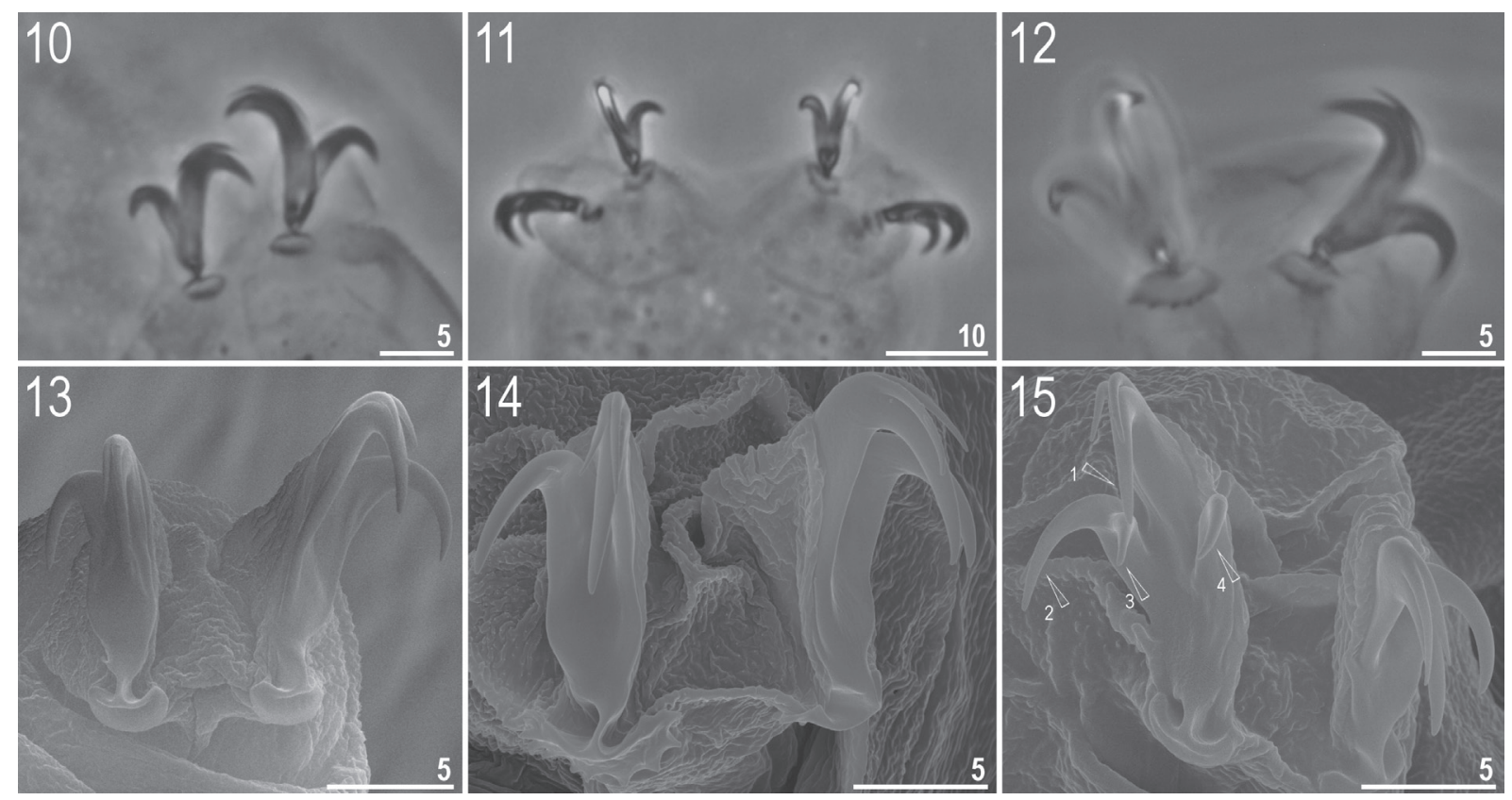

Figs 10-15. Claws. 10. Claw II with smooth lunules (PCM, paratype). 11. Claw IV (PCM, holotype). 12. Indented lunules on claw IV (PCM, paratype). 13. Claw I with smooth lunules (SEM, paratype). 14. Claw IV with indented lunules (SEM, paratype). 15. Aberrant claw IV (SEM, paratype). Numbers 1-2 indicate normally developed claw branches/spurs, whereas 3-4 indicate aberrant claw branches/ spurs. Scale bars in $\mu \mathrm{m}$. 
claws of the IV pair of legs, unique, upwardly turned spurs were present near the lower half of the claw (Fig. 19).

\section{Differential diagnosis}

\section{Morphological}

Macrobiotus polypiformis sp. nov., by the presence of long, flexible filaments on the egg processes and faint annular undulations on their trunks, is most similar to Ma. paulinae Stec et al., 2015, but differs from it by possessing larger pores on the cuticle $(0.9-1.2 \mu \mathrm{m}$ in Ma. polypiformis sp. nov. vs 0.3-0.5 $\mu \mathrm{m}$ in Ma.pauliane), smooth cuticle (seven dorso-lateral patches of sparse granulation arranged symmetrically on both sides of the body in Ma. paulinae), one patch of granulation on legs I-IV (two distinct patches of granulation, fine and dense granulation above claws and a more robust and sparse granulation in the middle of each leg in Ma. paulinae), a different number of rows of teeth in the first band of teeth in the oral cavity (3-4 rows in Ma. polypiformis sp. nov. vs a single row in Ma. paulinae), larger reticulum mesh diameter covering the egg surface $(0.5-0.8 \mu \mathrm{m}$ in Ma. polypiformis sp. nov. vs
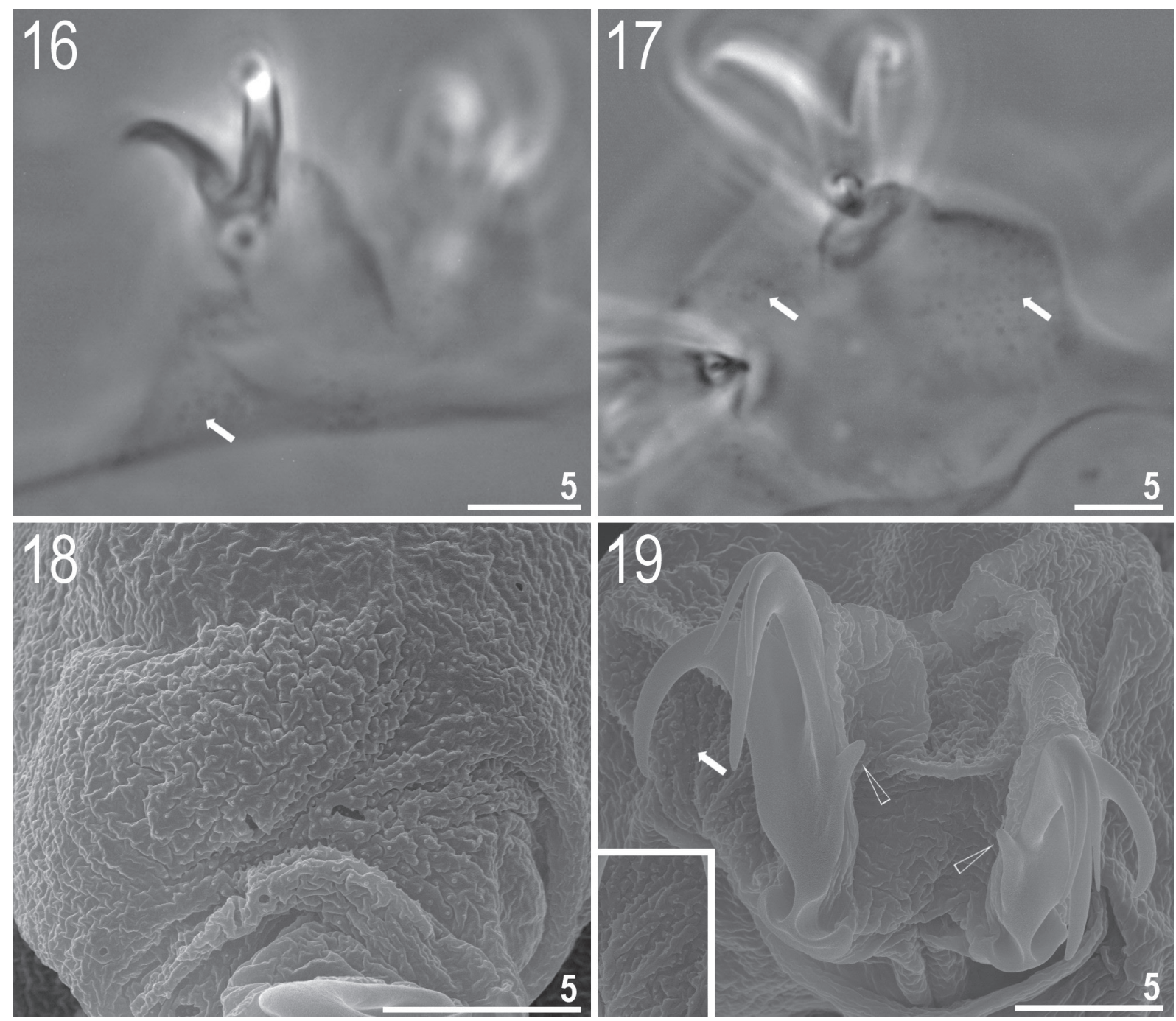

Figs 16-19. Macrobiotus polypiformis sp. nov., paratypes. 16. Granulation on the II pair of legs, arrow (PCM). 17. Granulation on IV pair of legs, arrow (PCM). 18. Granulation on II pair of legs (SEM). 19. Modified claw IV (arrowheads) and granulation on IV pair of legs, arrow (SEM). Scale bars in $\mu \mathrm{m}$. 
0.05-0.2 $\mu \mathrm{m}$ in Ma. paulinae), trunks of the egg processes with faint annular undulations (distinct and clearly visible in Ma. paulinae), different morphology of the terminal disc margins (8-10 long, hair-like, flexible filaments in Ma. polypiformis sp. nov. vs small, irregular teeth, instead of filaments, in Ma. paulinae, with only some processes having one to a few flexible filaments), lower number of processes on the egg circumference (19-23 in Ma. polypiformis sp. nov. vs 24-32 in Ma. paulinae).

\section{Genotypic}

It was confirmed, using Basic Local Alignment Search Tool (BLAST; Altschul et al. 1990), that no sequences deposited in GenBank were identical with sequences obtained from the type population of
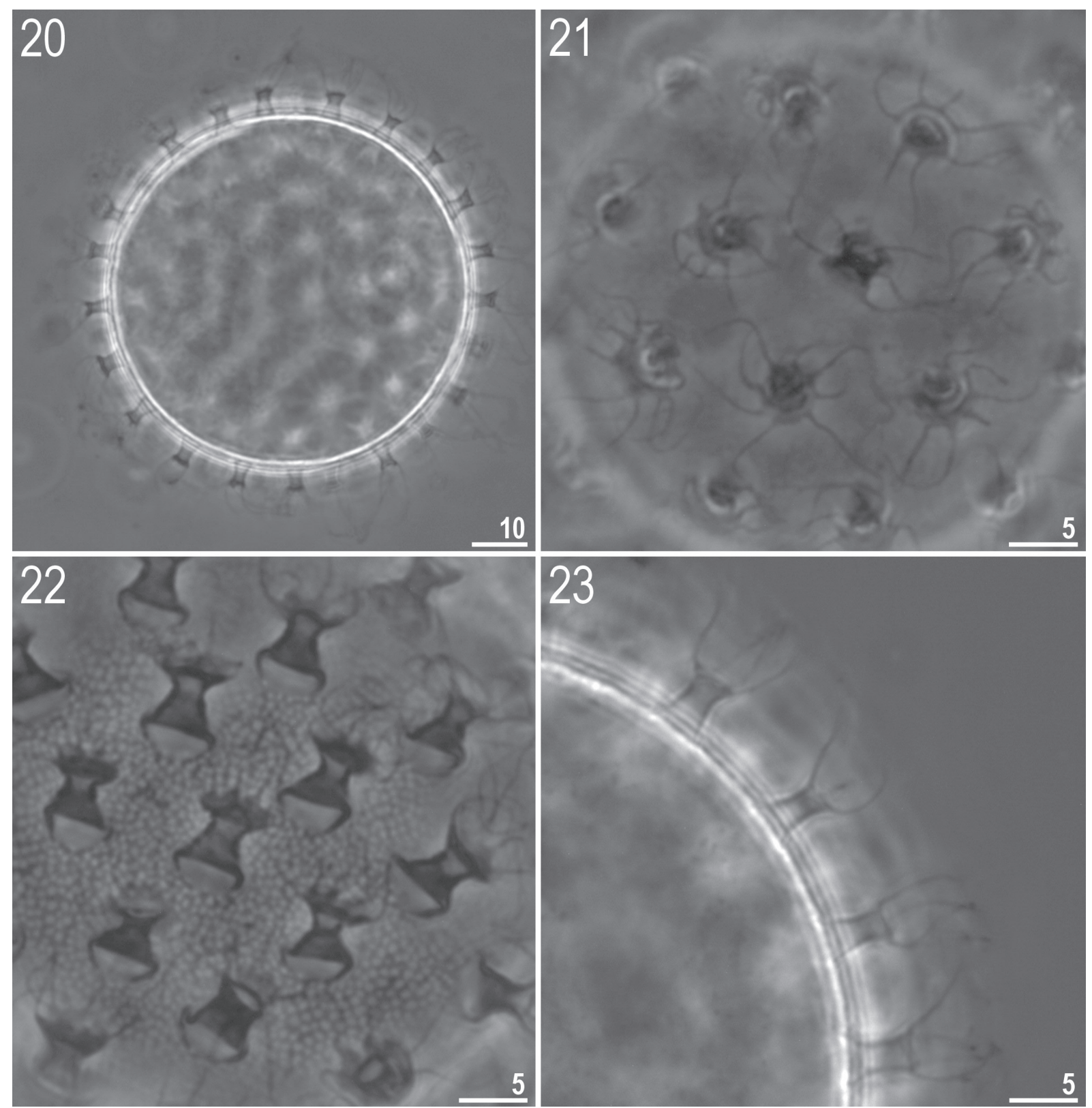

Figs 20-23. Macrobiotus polypiformis sp. nov. 20. Chorion. 21. Long, hair-like flexible filaments on terminal discs. 22. Egg processes and the surface between egg processes with reticular design. 23. Egg processes with filaments. All in PCM. Scale bars in $\mu \mathrm{m}$. 
Ma. polypiformis sp. nov. The p-distances calculated for ITS-2 between the new species and Ma. polonicus Pilato, Kaczmarek, Michalczyk \& Lisi, 2003, Ma. spaiens Binda \& Pilato, 1984 and Ma. paulinae are $39.4 \%, 25.6 \%$ and $31.1 \%$, respectively. In the case of COI, genetic distances between the two haplotypes of Ma. polypiformis sp. nov. is $3.1 \%$, which is above the threshold for species delineation proposed by Cesari et al. (2009). However, sequences from haplotype 1 and 2 are clearly distant from sequences of each species used in the analysis. For haplotype 1, p-distance range from $20.6 \%$ to $25.8 \%$; haplotype 2 from $21.0 \%$ to $25.9 \%$. In each case the most similar to the new species is Ma. paulinae (KT951668) and the most distinct is Ma. macrocalix Bertolani \& Rebecchi, 1993 (HQ876571, FJ176208-12). Given there is no polymorphism in the ITS-2 sequences coming from the type population and the morphologically most similar species $M a$. paulinae differs from the new species by a genetic distance of nearly $21 \%$, it can be claimed that Ma. polypiformis sp. nov. is a valid new species exhibiting two COI haplotypes. P-distances for more conservative DNA fragments (28S rRNA and 18S rRNA) are, as was expected, lower than for more variable markers (COI and ITS-2). The range for $28 \mathrm{~S}$ rRNA is $7.3 \%-12.9 \%$ with the most similar species Ma. paulinae (KT935501) and for 18S rRNA 3.0\%-6.2\% where the closest related species are Ma. paulinae (KT935502) and Ma. sapiens (DQ839601).

\section{Discussion}

\section{Remarks on claw abnormalities and taxonomic status of Me. armatus Pilato \& Binda, 1996}

The morphological abnormalities of some body parts (e.g., shape and size of shells, number, length and shape of body appendages or claws) in many groups of invertebrates, are reported quite frequently. However, the percentage of abnormally developed specimens is rather low in normal environmental conditions, but can be much higher in polluted environments (e.g., Geslin et al. 2002). The stress factors proposed as possible sources of higher rates of appearance of morphological abnormalities are
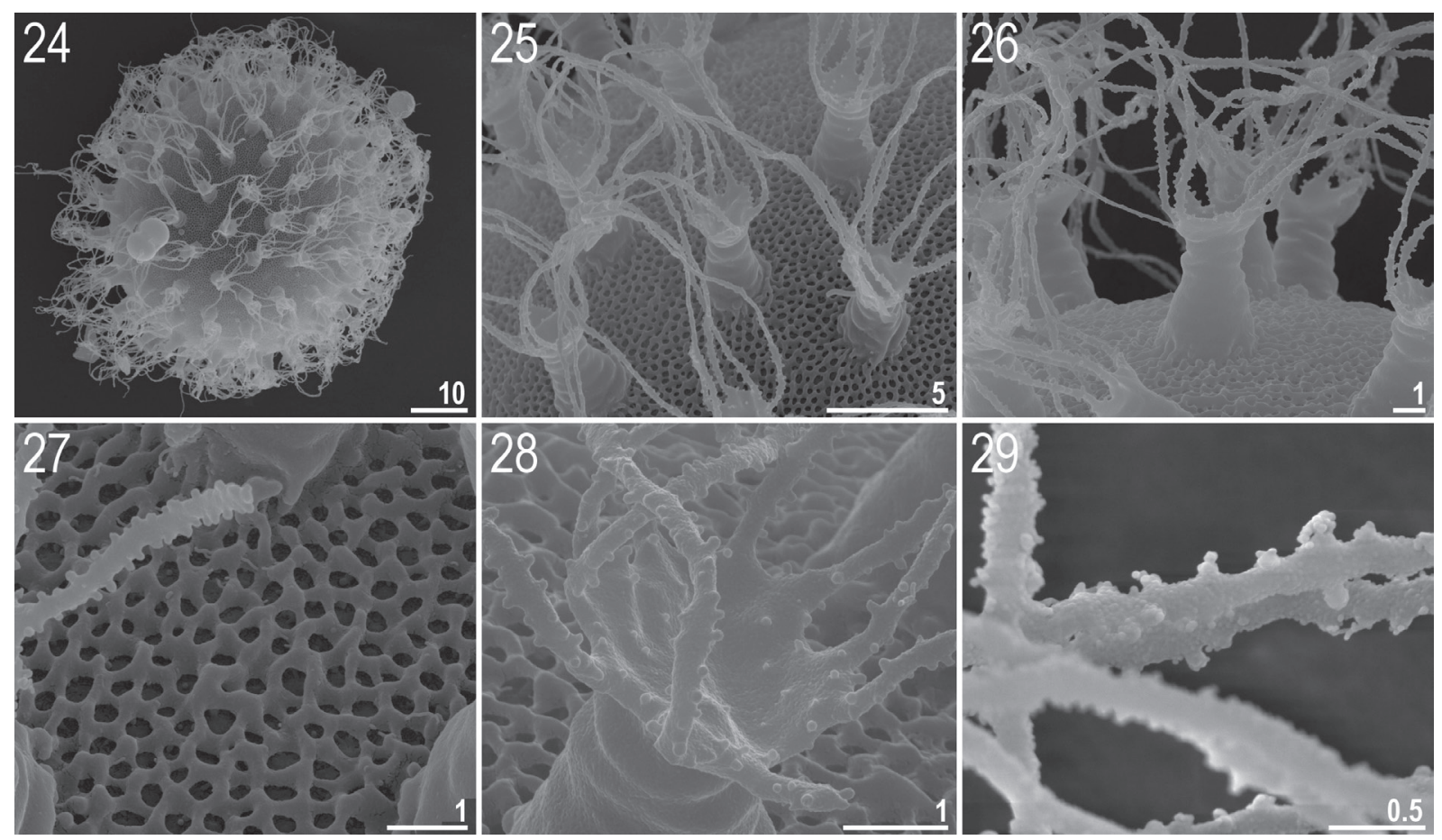

Figs 24-29. Macrobiotus polypiformis sp. nov. 24. Chorion. 25. Long, hair-like flexible filaments on terminal discs. 26. Egg processes with faint annular undulations. 27. Surface between egg processes with reticular design. 28. Terminal discs with small, randomly arranged granules. 29. Small granules on filaments. All in SEM. Scale bars in $\mu \mathrm{m}$. 
different types of pollution, radioactivity, and changes in salinity or heavy metals. Additionally, such morphological abnormalities were also proposed as a possible source of taxonomical problems and misidentifications (e.g., De Oliveira Dias 1999; Reinert 1999; Samir \& El-Din 2001; Elmoor-Loureiro 2004; Meriç et al. 2008; Zagal 2008; Głowska \& Skoracki 2009; Fransozo et al. 2012; Miličić et al. 2013; Méndez-de Daboín et al. 2015).

The number of claws and their morphology are very important in tardigrade taxonomy at the family, genus, and species levels. The presence or absence of accessory points, lunules (dentate or smooth) or spurs, as well as the length of all structures (e.g., of primary and secondary branches and spurs) together with their shapes, are very important at the species level in most tardigrade genera (e.g., Pilato \& Binda 2010; Marley et al. 2011). In most cases these structures are very conservative on the species level. However, some claw modifications, or rather abnormalities, have been observed in e.g., Ma. naskreckii Bąkowski et al., 2016, Milnesium sp. (reported as Mi. tardigradum Doyère, 1840), Mi. beasleyi Kaczmarek, Jakubowska \& Michalczyk, 2012 or Mi. reductum Tumanov, 2006 (Dastych 1984; Tumanov 2006; Michalczyk et al. 2012; Bąkowski et al. 2016). Similar abnormalities can be observed in Ma. polypiformis sp. nov. (Figs 15, 19). Sometimes such abnormalities are easy to recognise as in Ma. polypiformis sp. nov. (Figs 15, 19), Milnesium sp. (Dastych 1984: fig. 33), Mi. reductum (Tumanov 2006: figs 35-36) or Mi. beasleyi (Kaczmarek et al. 2012: fig. 11) as these additional spurs are usually much smaller, have a different shape, or are in an unusual place in comparison to other spurs on the claws of the same specimen. In other cases they can look like normally developed structures which are normal parts of the claws, especially when we observe only a single specimen instead of an entire population, as demonstrated in Ma. naskreckii (Bąkowski et al. 2016: figs 36-39) and Ma. polypiformis sp. nov. (Figs 15, 19). Unfortunately, specific studies focused on the presence of different kinds of abnormalities and their frequencies in tardigrades have never been conducted.

Mesobiotus armatus was described by Pilato \& Binda (1996) from New Zealand (Gillespies Beach, South Island). The authors examined about 60 specimens and eggs from various localities in New Zealand, attributed earlier to Me. liviae (Ramazzotti, 1962) by Horning et al. (1978). These specimens were consequently attributed to Me. diffusus (Binda \& Pilato, 1987), Me. hieronimi (Pilato \& Claxton, 1988), Me. montanus (Murray, 1910) and a new species Me. pseudoliviae (Pilato \& Binda, 1996). However, they found one very unusual specimen from Gillespies Beach, South Island, from which they described another new species, $M e$. armatus, mainly based on the presence of "spurs turned toward the apex" on the first three pairs of legs (Pilato \& Binda 1996: fig. 4c). According to the authors, another character which differentiated Me. armatus from other Mesobiotus species was the lower $p t$ value of the stylet support insertion point ( $p t 72.90$ ). However, recent studies have shown that this $p t$ value can be even lower in some species of this group (e.g., the minimum $p t$ of the stylet support insertion point in Me. pseudoblocki Roszkowska et al., 2016 is 71.5). The remaining characters in the description of Me. armatus were typical of other species within the genus Mesobiotus. Describing new species from genera like Macrobiotus, Mesobiotus or Paramacrobiotus without the eggs, which are critical to the correct identification of most of the species in these genera (e.g., Bertolani \& Rebecchi 1993; Kaczmarek et al. 2011), is highly risky. However, in the case of Me. armatus the presence of a unique character, in the form of spurs on claws, was considered sufficient to describe the new species, even based on only a single specimen. Based on recently published data (Tumanov 2006; Kaczmarek et al. 2012; Bąkowski et al. 2016) and on the observations from the present paper (see Remarks to the new species and Figs 15, 19), we can hypothesize that the decision to describe Me. armatus was premature. As is shown in Fig. 19, the same type of "spurs" as present in Me. armatus were found in one specimen of Ma. polypiformis sp. nov. and similar abnormalities were also present in a single specimen of $M a$. naskreckii. These findings suggest that the "spurs" found in Me. armatus may be an abnormality rather than a unique and constant character. This conclusion is further supported by the finding of only a single specimen of Me. armatus among the many other specimens of Mesobiotus (from many New Zealand 
localities) with normally developed claws. We, therefore, suggest that Me. armatus be considered species inquirenda (i.e., of uncertain taxonomic status) until such time as its validity as a species can be confirmed. The case of Me. armatus exposes a wider problem with the practice of describing tardigrade species based on a limited number of specimens (in extreme cases, species have been erected on the basis of a single specimen). We can conclude that such descriptions should only be accepted when supported by appropriate nucleotide sequences. Without these sequences, such descriptions may serve only to exaggerate tardigrade diversity. Similar conclusions were reached by Stec et al. (2016b), who demonstrated considerable egg variability in Ramazzottius subanomalus (Biserov, 1985). Ultimately, we suggest that tardigradologists should avoid describing new species based on scarce material and especially on a single specimen. Moreover, we think that all species previously described on the basis of a single specimen, or without eggs (for those species belonging to the genera in which eggs are indispensable to the correct species identification), should be confirmed and redescribed based on a larger sample.

\section{Acknowledgements}

The authors wish to thank Brian Blagden (Scottish Environment Protection Agency, UK) for his help in the English revision and for his suggestions on the manuscript. This work was partially supported by the Prometeo Project of the Secretariat for Higher Education, Science, Technology and Innovation of the Republic of Ecuador (grant to ŁK) and by the Homing Plus programme of the Foundation for Polish Science, co-funded by the European Union's Regional Development Fund (grant no. HP/2012-5/8 to Łukasz Michalczyk, Jagiellonian University, Poland). The research was partially carried out thanks to equipment purchased with the financial assistance of the European Regional Development Fund in the framework of the Polish Innovation Economy Operational Program (contract no. POIG.02.01.0012-023/08 to the Jagiellonian University, Poland). Studies have been conducted in the framework of activities of BARg (Biodiversity and Astrobiology Research group at the Adam Mickiewicz University in Poznań, Poland). We also wish to thank the Ministry of Education, Youth and Sports of the Czech Republic (project numbers: LM2015078 and CZ.02.1.01/0.0/0.0/15_003/0000460) for financial support.

\section{References}

Altschul S.F., Gish W., Miller W., Myers E.W. \& Lipman D.J. 1990. Basic local alignment search tool. Journal of Molecular Biology 215: 403-410. https://doi.org/10.1016/S0022-2836(05)80360-2

Bąkowski M., Roszkowska M., Gawlak M. \& Kaczmarek Ł. 2016. Macrobiotus naskreckii sp. nov. (Eutardigrada: Macrobiotidae: hufelandi group) from Mozambique. Annales Zoologici 66 (2): 155-164.

Bertolani R. \& Rebecchi L. 1993. A revision of the Macrobiotus hufelandi group (Tardigrada, Macrobiotidae), with some observations on the taxonomic characters of eutardigrades. Zoologica Scripta 22: 127-152. https://doi.org/10.1111/j.1463-6409.1993.tb00347.x

Bertolani R., Biserov V.I., Rebecchi L. \& Cesari M. 2011. Taxonomy and biogeography of tardigrades using an integrated approach: new results on species of the Macrobiotus hufelandi group. Invertebrate Zoology 8 (1): 23-36.

Bertolani R., Guidetti R., Marchioro T., Altiero T., Rebecchi L. \& Cesari M. 2014. Phylogeny of Eutardigrada: New molecular data and their morphological support lead to the identification of new evolutionary lineages. Molecular Phylogenetics and Evolution 76: 110-126. https://doi.org/10.1016/j. ympev.2014.03.006

Casquet J., Thebaud C. \& Gillespie R.G. 2012. Chelex without boiling, a rapid and easy technique to obtain stable amplifiable DNA from small amounts of ethanol-stored spiders. Molecular Ecology Resources 12: 136-141. https://doi.org/10.1111/j.1755-0998.2011.03073.x 
Cesari M., Bertolani R., Rebecchi L. \& Guidetti R. 2009. DNA barcoding in Tardigrada: the first case study on Macrobiotus macrocalix Bertolani \& Rebecchi 1993 (Eutardigrada, Macrobiotidae). Molecular Ecology Resources 9 (3): 699-706. https://doi.org/10.1111/j.1755-0998.2009.02538.x

Dastych H. 1980. Niesporczaki (Tardigrada) Tatrzańskiego Parku Narodowego. Monografie Fauny Polski 9, PWN, Krakow.

Dastych H. 1984. The Tardigrada from Antartica with description of several new species. Acta Zoologica Cracoviensia 27: 377-436.

Degma P. \& Guidetti R. 2007. Notes to the current checklist of Tardigrada. Zootaxa 1579: 41-53.

Degma P., Bertolani R. \& Guidetti R. 2009-2016. Actual checklist of Tardigrada species. (v. 31: 15 Dec. 2016). Available from www.tardigrada.modena.unimo.it/miscellanea/Actual $\% 20$ checklist $\% 20$ of $\% 20$ Tardigrada.pdf [accessed 6 Apr. 2017].

De Oliveira Dias C. 1999. Morphological abnormalities of Acartia lilljeborgi (Copepoda, Crustacea) in the Espirito Santo Bay (E.S. Brazil).Hydrobiologia 394:249-251.https://doi.org/10.1023/A:1003502624336

Elmoor-Loureiro L.M. 2004. Morphological abnormalities in the cladoceran Ilyocryptus spinifer (Apipucos Reservoir, Pernambuco State, Brazil). Brazilian Journal of Biology 64 (1): 53-58. https:// doi.org/10.1590/S1519-69842004000100007

Folmer O., Black M., Hoeh W., Lutz R. \& Vrijenhoek R. 1994. DNA primers for amplification of mitochondrial cytochrome c oxidase subunit I from diverse metazoan invertebrates. Molecular Marine Biology and Biotechnology 3: 294-299.

Fransozo A., Teixeira G.M., Gomes R.R., Silva J.C. \& Bolla Jr. E.A. 2012. Ocorrência de anormalidades morfológicas externas em caranguejos marinhos (Decapoda, Brachyura) no litoral norte do estado de São Paulo. Acta Scientiarum - Biological Sciences 34 (1): 101-104.

Geslin E., Debenay J., Duleba W. \& Bonetti C. 2002. Morphological abnormalities of foraminiferal tests in Brazilian environments: comparison between polluted and non-polluted areas. Marine Micropaleontology 45 (2): 151-168. https://doi.org/10.1016/S0377-8398(01)00042-1

Głowska E. \& Skoracki M. 2009. Anomalous chaetotaxy in the quill mites Torotrogla merulae Skoracki et al., 2000 (Acari, Prostigmata, Syringophilidae). Acta Parasitologica 54 (4): 364-367. https://doi. org/10.2478/s11686-009-0046-y

Guidetti R. \& Bertolani R. 2005. Tardigrade taxonomy: an updated check list of the taxa and a list of characters for their identification. Zootaxa 845: 1-46.

Guidetti R., Altiero T., Marchioro T., Sarzi Amadè L., Avdonina A.M., Bertolani R. \& Rebecchi L. 2012. Form and function of the feeding apparatus in Eutardigrada (Tardigrada). Zoomorphology 131 (2): 127-148. https://doi.org/10.1007/s00435-012-0149-0

Guidetti R., Peluffo J.R., Rocha A.M., Cesari M. \& Moly de Peluffo M.C. 2013. The morphological and molecular analyses of a new South American urban tardigrade offer new insights on the biological meaning of the Macrobiotus hufelandi group of species (Tardigrada: Macrobiotidae). Journal of Natural History 47: 2409-2426. https://doi.org/10.1080/00222933.2013.800610

Guil N. \& Giribet G. 2012. A comprehensive molecular phylogeny of tardigrades - adding genes and taxa to a poorly resolved phylum-level phylogeny. Cladistics 28 (1): 21-49. https://doi.org/10.1111/ j.1096-0031.2011.00364.x

Hall T.A. 1999. BioEdit: a user-friendly biological sequence alignment editor and analysis program for Windows 95/98/NT. Nucleic Acids Symposium Series 41: 95-98. 
Hebert P.D.N., Cywinska A., Ball S.L. \& de Waard J.R. 2003. Biological identifications through DNA barcodes. Proceedings of the Royal Society of London, Series B 270: 313-322. https://doi.org/10.1098/ $\underline{\mathrm{rspb} .2002 .2218}$

Horning D.S., Schuster R.O. \& Grigarick A.A. 1978. Tardigrada of New Zealand. New Zealand Journal of Zoology 5: 185-280. https://doi.org/10.1080/03014223.1978.10428316

Kaczmarek Ł., Goldyn B., Prokop Z.M. \& Michalczyk Ł. 2011. New records of Tardigrada from Bulgaria with the description of Macrobiotus binieki sp. nov. (Eutardigrada: Macrobiotidae) and a key to the species of the harmsworthi group. Zootaxa 2781: 29-39.

Kaczmarek Ł., Jakubowska N. \& Michalczyk Ł. 2012. Current knowledge on Turkish tardigrades with a description of Milnesium beasleyi sp. nov. (Eutardigrada: Apochela: Milnesiidae, the granulatum group). Zootaxa 3589: 49-64.

Kaczmarek Ł., Cytan J., Zawierucha K., Diduszko D. \& Michalczyk Ł. 2014. Tardigrades from Peru (South America), with descriptions of three new species of Parachela. Zootaxa 3790 (2): 357-379. https://doi.org/10.11646/zootaxa.3790.2.5

Kaczmarek Ł., Michalczyk Ł. \& McInnes S.J. 2015. Annotated zoogeography of non-marine Tardigrada. Part II: South America. Zootaxa 3923 (1): 1-107. https://doi.org/10.11646/zootaxa.3923.1.1

Kaczmarek Ł., Michalczyk Ł. \& McInnes S.J. 2016. Annotated zoogeography of non-marine Tardigrada. Part III: North America and Greenland. Zootaxa 4203 (1): 001-249. https://doi.org/10.11646/ zootaxa.4203.1.1

Londoño R., Daza A., Caicedo M., Quiroga S. \& KaczmarekŁ. 2015. The genus Milnesium (Eutardigrada: Milnesiidae) in the Sierra Nevada de Santa Marta (Colombia), with the description of Milnesium kogui sp. nov. Zootaxa 3955 (4): 561-568. https://doi.org/10.11646/zootaxa.3955.4.7

Marley N.J., McInnes S.J. \& Sands C.J. 2011. Phylum Tardigrada: a re-evaluation of the Parachela. Zootaxa 2819: 51-64.

McInnes S.J. 1994. Zoogeographic distribution of terrestrial/freshwater tardigrades from current literature. Journal of Natural History 28: 257-352. https://doi.org/10.1080/00222939400770131

Méndez-de Daboín Y., Oviedo-Araújo M., González-Pérez A., Suárez-Hernández J., Sandoval C.M. \& Cazorla D. 2015. Anomalías morfológicas en los dientes del cibario de Lutzomyia evansi (Diptera: Psychodidae) en el estado Trujillo, Venezuela. Biomedica 35 (2): 269-273.

Meriç E., Avşar N., Yokeş M.B., Tuğrul A.B., Bayari S., Özyurt N., Barut I.F., Balkis N., Uysal K. \& Kam E. 2008. Morphological abnormalities in benthic foraminifers of the Antalya coast. Micropaleontology 54 (3-4): 241-276.

Michalczyk Ł. \& Kaczmarek Ł. 2003. A description of the new tardigrade Macrobiotus reinhardti (Eutardigrada: Macrobiotidae, harmsworthi group) with some remarks on the oral cavity armature within the genus Macrobiotus Schultze. Zootaxa 331: 1-24.

Michalczyk Ł. \& Kaczmarek Ł. 2013. The Tardigrada Register: a comprehensive online data repository for tardigrade taxonomy. Journal of Limnology 72 (S1): 175-181. https://doi.org/10.4081/jlimnol.2013. $\underline{\text { s1.e22 }}$

Michalczyk Ł., Wełnicz W., Frohme M. \& Kaczmarek Ł. 2012. Redescriptions of three Milnesium Doyère, 1840 taxa (Tardigrada: Eutardigrada: Milnesiidae), including the nominal species for the genus. Zootaxa 3154: 1-20. 
Miličić D., Pavković-Lučić S. \& Lučić L. 2013. On some morphological abnormalities in adult fairy shrimp Branchipus schaefferi Fischer, 1834, from Serbia. Archives of Biological Sciences 65 (4): 16451650. https://doi.org/10.2298/ABS1304645M

Mironov S.V., Dabert J. \& Dabert M. 2012. A new feather mite species of the genus Proctophyllodes Robin, 1877 (Astigmata: Proctophyllodidae) from the Long-tailed Tit Aegithalos caudatus (Passeriformes: Aegithalidae): morphological description with DNA barcode data. Zootaxa 3253: 54-61.

Morek W., Gąsiorek P., Stec D., Blagden B \& Michalczyk Ł. 2016. Experimental taxonomy exposes ontogenetic variability and elucidates the taxonomic value of claw configuration in Milnesium Doyère, 1840 (Tardigrada: Eutardigrada: Apochela). Contributions to Zoology 85 (2): 173-200.

Nelson D.R., Guidetti R. \& Rebecchi L. 2015. Chapter 17: Phylum Tardigrada. In: Thorp J. \& Rogers D.C. (eds) Ecology and General Biology. Vol. 1: 347-380. Thorp and Covich's Freshwater Invertebrates (4th edition), Elsevier, Amsterdam.

Pilato G. 1981. Analisi di nuovi caratteri nello studio degli Eutardigradi. Animalia 8: 51-57.

Pilato G. \& Binda M.G. 1996. Two new species and new records of Macrobiotus (Eutardigrada) from New Zealand. New Zealand Journal of Zoology 23: 375-379.

Pilato G. \& Binda M.G. 2010. Definition of families, subfamilies, genera and subgenera of the Eutardigrada, and keys to their identification. Zootaxa 2404: 1-52.

Ramazzotti G. \& Maucci W. 1983. Il Phylum Tardigrada. Memorie dell'Istituto Italiano di Idrobiologia, Pallanza 41, Istituto Italiano di Idrobiologia, Verbania.

Reinert J.F. 1999. Morphological abnormalities in species of the quadrimaculatus complex of Anopheles (Diptera: Culicidae). Journal of the American Mosquito Control Association 15 (1): 8-14.

Roszkowska M., Ostrowska M. \& Kaczmarek Ł. 2015. The genus Milnesium Doyère, 1840 (Tardigrada) in South America with descriptions of two new species from Argentina and discussion of the feeding behaviour in the family Milnesiidae. Zoological Studies 54: 1-17. https://doi.org/10.1186/s40555-014$\underline{0082-7}$

Roszkowska M., Stec D., Ciobanu D.A. \& Kaczmarek Ł. 2016. Tardigrades from Nahuel Huapi National Park (Argentina, South America) with descriptions of two new Macrobiotidae species. Zootaxa 4105 (3): 243-260. https://doi.org/10.11646/zootaxa.4105.3.2

Samir A.M. \& El-Din A.B. 2001. Benthic foraminiferal assemblages and morphological abnormalities as pollution proxies in two Egyptian bays. Marine Micropaleontology 41 (3-4): 193-227. https://doi. org/10.1016/S0377-8398(00)00061-X

Sands C.J., Mcinnes S.J., Marley N.J., Goodall-Copestake W., Convey P. \& Linse K. 2008. Phylum Tardigarda: an "individual" approach. Cladistics 24 (6): 861-871. https://doi.org/10.1111/j.1096$\underline{0031.2008 .00219 . x}$

Schill R.O., Forster F., Dandekar T. \& Wolf N. 2010. Using compensatory base change analysis of internal transcribed spacer 2 secondary structures to identify three new species in Paramacrobiotus (Tardigrada). Organisms Diversity \& Evolution 10 (4): 287-296. https://doi.org/10.1007/s13127-010$\underline{0025-\mathrm{Z}}$

Stec D., Smolak R., Kaczmarek Ł. \& Michalczyk Ł. 2015. An integrative description of Macrobiotus paulinae sp. nov. (Tardigrada: Eutardigrada: Macrobiotidae: hufelandi group) from Kenya. Zootaxa 4052 (5): 501-526. https://doi.org/10.11646/zootaxa.4052.5.1 
Stec D., Gąsiorek P., Morek W., Kosztyła P., Zawierucha K., Michno K., Kaczmarek Ł., Prokop Z.M. \& Michalczyk Ł. 2016a. Estimating optimal sample size for tardigrade morphometry. Zoological Journal of the Linnean Society 178 (4): 776-784. https://doi.org/10.1111/zoj.12404

Stec D., Morek W., Gąsiorek P., Kaczmarek Ł. \& Michalczyk Ł. 2016b. Determinants and taxonomic consequences of extreme egg shell variability in Ramazzottius subanomalus (Biserov, 1985) (Tardigrada). Zootaxa 4208 (2): 176-188. https://doi.org/10.11646/zootaxa.4208.2.5

St Louis R., Burningham L., Dowl A. \& Grosberg M. 2009. Lonely Planet Guide: Ecuador \& the Galápagos Islands. Lonely Planet, New York.

Tamura K., Dudley J., Nei M. \& Kumar S. 2007. MEGA4: Molecular Evolutionary Genetics Analysis (MEGA) software version 4.0. Molecular Biology and Evolution 24: 1596-1599. https://doi.org/10.1093/ molbev/msm092

Thompson J.D., Higgins D.G. \& Gibson T.J. 1994. CLUSTAL W: Improving the sensitivity of progressive multiple sequence alignment through sequence weighting, positionspecific gap penalties and weight matrix choice. Nucleic Acids Research 22 (22): 4673-80.

Tumanov D.V. 2006. Five new species of the genus Milnesium (Tardigrada, Eutardigrada, Milnesiidae). Zootaxa 1122: 1-23.

Vicente F. \& Bertolani R. 2013. Considerations on the taxonomy of the Phylum Tardigrada. Zootaxa 3626: 245-248. https://doi.org/10.11646/zootaxa.3626.2.2

Wełnicz W., Grohme M.A., Kaczmarek Ł., Schill R.O. \& Frohme M. 2011. ITS-2 and 18S rRNA data from Macrobiotus polonicus and Milnesium tardigradum (Eutardigrada, Tardigrada). Journal of Zoological Systematics and Evolutionary Research 49 (S1): 34-39. https://doi.org/10.1111/j.1439$\underline{0469.2010 .00595 . \mathrm{X}}$

White T.J., Bruns T., Lee S. \& Taylor J. 1990. PCR protocols: a guide to methods and application: 315-322. Academic Press, San Diego, California.

Zagal C.J. 2008. Morphological abnormalities in the stauromedusa Haliclystus auricula (Cnidaria) and their possible causes. Journal of the Marine Biological Association of the United Kingdom 88 (2): 259-262. https://doi.org/10.1017/S0025315408000179

Manuscript received: 3 June 2016

Manuscript accepted: 1 September 2016

Published on: 7 June 2017

Topic editor: Rudy Jocqué

Desk editor: Kristiaan Hoedemakers

Printed versions of all papers are also deposited in the libraries of the institutes that are members of the EJT consortium: Muséum national d'Histoire naturelle, Paris, France; Botanic Garden Meise, Belgium; Royal Museum for Central Africa, Tervuren, Belgium; Natural History Museum, London, United Kingdom; Royal Belgian Institute of Natural Sciences, Brussels, Belgium; Natural History Museum of Denmark, Copenhagen, Denmark; Naturalis Biodiversity Center, Leiden, the Netherlands; Museo Nacional de Ciencias Naturales-CSIC, Madrid, Spain; Real Jardín Botánico de Madrid CSIC, Spain. 